\title{
A zálogjogosult bekapcsolódása a végrehajtási eljárásba
}

\author{
bírósági végrehajtás - zálogjogosult - zálogjog érvényesitése - \\ bekapcsolódás - kielégítési elsőbbség
}

\begin{abstract}
A zálogjog a polgári jog kétarcú jogintézménye. Megtalálhatóak benne a kötelmi és dologi joghoz kapcsolódó elemek is. A zálogjog egyrészről szerződést biztosító mellékkötelezettség, ami azt jelenti, hogy a szerződést kötő felek kötelmi jogi ügyletük biztosítékaként alapítják a zálogjogot, másrészt korlátolt dologi jog, amely alapján a zálogjog nemcsak a felek közötti jogviszonyban, hanem minden kívüláló irányában joghatást vált ki. A zálogjog ugyanis abban az esetben is fennmarad, ha a zálogkötelezett átruházza a dolog tulajdonjogát, mivel azt az új tulajdonos zálogjoggal terhelten szerzi meg. A zálogjogosultat a zálogtárgy mindenkori tulajdonosával szemben megilleti az a jog, hogy követelését a zálogtárgyból kielégítse. Ezenkívül a zálogjog dologi jogi jellegét jellemzi, hogy zálogjog nem csupán a kötelmi jogi ügylet kötelezettjét, hanem más személyt is terhelhet. llyen esetben a személyes adós és a zálogkötelezett (dologi kötelezett) személye elválik egymástól. A zálogkötelezett nem köteles a követelés megtérítésére, hanem csupán annak türésére, hogy ha az adós nem teljesít, a zálogjogosult a követelését a zálogtárgyból kielégítse. ${ }^{1}$

A Polgári Törvénykönyvröl szóló 1959. évi IV. törvény (régi Ptk.) miniszteri indokolása szerint a kielégitési jog központi jelentőségéből következik, hogy a zálogjogi szabályozás lényegét azok a rendelkezések alkotják, amelyek a kielégítés módját rendezik. ${ }^{2} \mathrm{~A}$ törvény a zálogjogosult részére kielégítési elsőbbséget biztosít a biztosítékként lekötött vagyontárgy felett, a hitelező tehát más jogosultakat megelőzően kereshet kielégítést. Az elsőbbségi jog a zálogkötelezett tulajdonát korlátozó, dologi jellegü jog. Ezért különösen hangsúlyosak a zálogjog érvényesítésére irányadó szabályok. Ezek határozzák meg a zálogjog hitelbiztositéki erejét, továbbá a zálogjog
\end{abstract}

* Dr. Kovács-Hegedüs Vera bírósági titkár, Budapesti XX., XXI. és XXIII. Kerületi Bíróság (munkáltató: Fővárosi Törvényszék), hegedusvera@gmail.com, hegedusv@csepel.birosag.hu.

1 A régi Ptk. a zálogjog hitelbiztosítéki funkcióját, továbbá a szerződést biztosító mellékkötelezettségek egységes szabályozását tekintette elsődlegesnek, ezért a zálogjogi szabályokat a törvény kötelmi jogi részében, a szerzödést biztosító mellékkötelezettségek között helyezte el. Ehhez képest a Polgári Törvénykönyvröl szóló 2013. évi V. törvény (új Ptk.) a zálogjog dologi jogi jellegét tekinti elsődlegesnek, ezért a Dologi jogi könyvben szabályozza. Az új Ptk. a zálogjogot teszi az elsődleges dologi jogi biztosítékká, kimondja a fiduciárius biztosítékok - tulajdonátruházás, engedményezés, illetve vételi jog biztosítéki célú alkalmazása - tilalmát. Az új kódex a jogintézmény lényegén nem változtatott, a hangsúlyokat tolta el.

2 A Magyar Népköztársaság Polgári Törvénykönyve - Az 1959. évi IV. törvény és a törvény javaslatának miniszteri indokolása. Közgazdasági és Jogi Könyvkiadó, Budapest, 1963, 279. 
lényegét éppen értékjogi jellege adja, ami pedig az érvényesítésre vonatkozó szabályokból következik. ${ }^{3} \mathrm{~A}$ zálogjogosult kielégítési joga megnyílása esetén, amenynyiben az adós nem teljesít, választása szerint fordulhat a személyes adós ellen, és követelése kielégítése céljából végrehajtást indíthat, amely során a hitelező kérelme és a fokozatosság elve szerint az eljárás az adós teljes vagyona ellen irányulhat. Dönthet azonban úgy is a hitelezö, hogy követelését zálogjoga útján érvényesíti, ez esetben kérheti végrehajtás elrendelését arra nézve, hogy a zálogkötelezett türje, hogy a zálogtárgyból a követelését kielégítse. A zálogkötelezett - amennyiben nem személyes adós is egyben - nem köteles a követelés teljesítésére, azonban a zálogtárgyra vezetett végrehajtás elkerülése érdekében jogosult teljesíteni. A hitelezőt sortartás nem terheli, tehát anélkül érvényesítheti követelését a zálogtárgyból, hogy elötte a pénzkövetelését próbálná behajtani.

A Polgári Törvénykönyvröl szóló 2013. évi V. törvény (új Ptk.) alapján fő szabálylyá a zálogjog bírósági végrehajtáson kívüli érvényesítése vált. ${ }^{5} \mathrm{~A}$ régi Ptk. ezzel ellentétben a zálogjog bírósági végrehajtás, illetve a felszámolás útján történő érvényesítését tekintette elsődlegesnek: végrehajtásra végrehajtható határozat alapján kerülhetett sor. A bírósági végrehajtásról szóló 1994. évi LIII. törvény (Vht.) alapján végrehajtási lap állítható ki ítélet, bírósági meghagyás, végzéssel jóváhagyott egyezség alapján, amelyet per előz meg, ezért az érvényesítés hosszabb időt is igénybe vehet. A peres eljárás elkerülhető, ha a felek a biztosított követelésről szóló szerződésüket közokiratba foglalják, vagy a zálogszerződésröl készítenek közokiratot, ez alapján per nélkül végrehajtási záradék kiállításával indulhat végrehajtás. ${ }^{6}$

A zálogjog érvényesítésének speciális, mind a régi, mind az új Ptk. szabályozási környezetében tipikus esete, amikor az adóssal szemben végrehajtási eljárás indul, és ezen eljárásba belépve érvényesíti a zálogjogosult a zálogjogi igényét. Ekkor a zálogjog érvényesítésére a zálogtárgy fedezeti jellegének és a zálogjogosult kielégítési elsőbbségének megóvása érdekében kerül sor, ugyanis a zálogkötelezett ellen - nem a zálogjoggal biztosított követelés behajtása iránt - indul a végrehajtás, amely során a zálogtárgyat értékesíteni lehet.

Ez utóbbi érvényesítési mód képezi jelen tanulmány témáját. A tanulmány a Budapest Környéki és a Fővárosi Törvényszéken szerzett gyakorlati tapasztalatok és a témát érintő, belső (bírósági használatra készült) anyagok alapján készült el. Utóbbiak képezik az általánosan elterjedt joggyakorlatra vonatkozó megállapítások alapját, valamennyi egyedi döntés szerepeltetése szétfeszítette volna a tanulmány kereteit.

3 MenYHÁRD Attila: Dologi jog. Osiris, Budapest, 2007, 448.

4 Az új Ptk. 5:126. § (3) bekezdése alapján a zálogjog bírósági végrehajtáson kívüli érvényesítéséhez nincsen szükség sem a zálogkötelezett beleegyezésére, sem a felek megállapodására. A törvény ezzel kívánja elérni, hogy a zálogjog mint elsődleges dologi biztosíték valóban hatékony eszközzé váljon a hitelezők számára.

5 Osztovits András (szerk.): A Polgári Törvénykönyvröl szóló 2013. évi V. törvény és a kapcsolódó jogszabályok nagykommentárja. Opten, Budapest, 2014, 668; továbbá a Polgári Törvénykönyvröl szóló 2013. évi V. törvény (Ptk.) 5:41. § (4) bekezdése.

6 Salamonné Solymosı Ibolya: A szerződések biztositékai. Agrocent, Vác, 1999, 132-133. 


\section{A zálogjogosult bekapcsolódása a végrehajtási eljárásba - az intézmény célja}

A zálogjogosult kielégitési elsőbbsége sokáig nem érvényesült megfelelően a végrehajtási eljárásban. A zálogjogosulti bekapcsolódásról először a bírósági végrehajtásról szóló 1979. évi 18. törvényerejü rendelet 83. §-a rendelkezett „elsőbbségi igény bejelentése" cím alatt. A rendelet csak az ingóságok esetén biztosította a bekapcsolódást, az ingatlan-végrehajtás során nem. Az ingó- és ingatlan-végrehajtásba csak 2001. szeptember 1-jétöl, a 2000. évi CXXXVI. törvény hatálybalépésétől kezdődően van lehetőség, a szabályozást később módosította a 2008. évi XXXIX. törvény.

A bírósági végrehajtásról szóló 1994. évi LIII. törvény (Vht.) úgy rendelkezik, hogy a zálogjogosult a végrehajtási eljárásba bekapcsolódhat, és a zálogjoggal biztosított követelését érvényesítheti, ha más személy végrehajtást indít a zálogkötelezett ellen, amelynek során a zálogtárgyat értékesítés céljából lefoglalják. Ez esetben a lefoglalás nyitja meg a kielégítési jogot. ${ }^{7}$ A végrehajtási eljárásba történő bekapcsolódásra azért van szükség, mert enélkül a zálogjogosult a zálogtárgy értékesítése (árverése) során befolyt vételárból nem részesülhetne, és követelésének biztosítéka elveszne. Az árverés következtében a zálogjog ugyanis megszűnik. ${ }^{8} A$ hatósági árverés útján történő tulajdonszerzés eredeti szerzésmód, ezért a dolgon megszünnek a harmadik személynek a dolgot terhelő jogai, kivéve, ha a hatósági határozattal vagy hatósági árverés útján szerző e jogok tekintetében nem volt jóhiszemü.

A jogviszonyra vonatkozó speciális törvény, a Vht. 137. § (1) bekezdése részben ugyan áttöri a fenti szabályt, és úgy rendelkezik, hogy ingatlan esetében egyes jogok fennmaradnak az eredeti szerzés ellenére is. Ezen jogok a következők lehetnek: a telki szolgalmi jog, közérdekú használati jog, ingatlan-nyilvántartásba bejegyzett haszonélvezeti jog, illetve törvényen alapuló haszonélvezeti jog. Ebböl következik, hogy - az ingókhoz hasonlóan - az ingatlant sem terheli zálogjog az árverést követően.

A zálogjogosult kielégítési elsőbbsége azonban a végrehajtás során csupán korlátozottan érvényesül. Ha a zálogtárgy értékesítéséből befolyt vételár nem fedezi valamennyi követelést, a pénzösszeg felosztására a Vht. kielégítési sorrendet állít fel a követelések jogcíme és az időbeliség, azaz a zálogjog, illetve a végrehajtási jog bejegyzésének rangsora alapján. Ingó dolgok esetében a zálogjogosultat csak a végrehajtás kezdeményezésével, elrendelésével és foganatosításával felmerült költségek ${ }^{9}$ előzik meg. $A z$ ingatlan, valamint vízi, légi jármű vételárából azonban a gyermektartásdijak, jogszabályon alapuló egyéb tartásdíjak és a munkabérek, illetve azzal egy tekintet alá eső járandóságok is megelőzik a zálogjoggal biztosított

Balogh Olga-B. Korek llona-CsÁsztı Ferenc-JuhÁsz Edit: A megújult bírósági végrehajtás. HVG-ORAC, Budapest, 2004, 296.

8 KAPA Mátyás: Ha az adós nem fizet. Második, átdolgozott kiadás. HVG-ORAC, Budapest, 2012, 54.

9 E körbe tartozik a le nem rótt illeték, az állam által elölegezett költség, a rendőri közremüködéssel felmerült költség, a végrehajtó készkiadása, költségátalánya, munkadíja, a Magyar Bírósági Végrehajtói Kamarának járó költségátalány, a végrehajtó behajtási jutaléka, továbbá a végrehajtást kérőnek a végrehajtás elrendelésével és foganatosításával járó költsége. Vht. 169-170. §. 
követelés kielégítését. ${ }^{10}$ Jelzálogjoggal biztosított több követelést a bejegyzett jelzálogjogok rangsorában lehet kielégíteni. A Vht. 170. § (3) bekezdése érvényesíti a 138. $§(6)$ bekezdése szerinti elvet és kimondja, hogy ha a jelzálogjog ingatlan-nyilvántartásba történő bejegyzésére a végrehajtási jog ranghelyét követöen került sor, azaz a zálogjogosult abban a tudatban alapította a zálogjogot, hogy az ingatlant már végrehajtási eljárásban lefoglalták, a jelzálogjoggal biztosított követelést csak azon követelést követően lehet kielégíteni, amelyre a végrehajtási jog vonatkozik.

A bekapcsolódás az adósra nézve hátrányos lehet, hiszen a végrehajtásba olyan zálogjogosult is bekapcsolódhat, aki nagyobb követelést érvényesít az adóssal szemben, mint amire az alapvégrehajtás folyik. Emellett a zálogjogosult abban az esetben is a teljes követelést érvényesítheti, ha az még nem esedékes, a zálogtárgy lefoglalásának ténye ugyanis a követelést lejárttá teszi.

\section{A végrehajtói felhívás}

Ahhoz, hogy a zálogjogosult érvényesíteni tudja kielégítési elsőbbségét, tudomást kell szereznie arról, hogy a követelést biztosító zálogtárgyat a végrehajtó lefoglalta. Erröl a végrehajtó felhívása alapján értesül.

Már itt meg kell azonban jegyezni, hogy a bekapcsolódás iránti kérelem előterjesztésének nem feltétele a végrehajtói felhívás. A zálogjogosult a kérelmet akkor is elöterjesztheti, ha a végrehajtótól nem kapott felhívást, azonban a zálogtárgyat lefoglalták. A kielégítési jog megnyíltát ugyanis a foglalás megtörténte alapján kell megállapítani, azt nem a végrehajtó felhívása keletkezteti. A végrehajtó - a kielégítési elsőbbség biztosítása érdekében - a végrehajtható okirat postán történő kézbesítése esetén az okirat megküldésével együtt felhívja az adóst, hogy 15 napon belül nyilatkozzon a vagyontárgyait terhelő zálogjogról. Így tesz a végrehajtó helyszíni foglalás esetén is. Ha a végrehajtó egyedi azonosításra kétséget kizáróan alkalmas vagyontárgyat foglal, hivatalból, egyébként a végrehajtást kérő kérelmére megkeresi a Magyar Országos Közjegyzői Kamara által vezetett zálogjogi nyilvántartást, szerepel-e a nyilvántartásban az adós zálogkötelezettként, vagyonát, vagyontárgyát terheli-e zálogjog. Az új Ptk. hatálybalépése folytán változott a Vht. 114. § (1) bekezdése is, 2014. március 15-étől kezdődően ugyanis a végrehajtó feladatává vált, hogy a hitelbiztositéki nyilvántartás ${ }^{11}$ adatait is beszerezze.

10 Varga István (szerk.): A polgári nemperes eljárások joga. ELTE Eötvös, Budapest, 2010, 267.

11 A hitelbiztosítéki rendszer reformja keretében az új Ptk. valamennyi jelzálogjog esetében kötelezővé teszi annak nyilvántartásba történő bejegyzését, a forgalom biztonságának növelése érdekében. Az ingatlanon alapított zálogjogot továbbra is az ingatlan-nyilvántartásba, a lajstromozott ingóságokon létrejött zálogjogot a lajstromba, minden más, így az egyéb ingóságon, jogon, követelésen alapított zálogjogot pedig a hitelbiztosítéki nyilvántartásba kell bejegyezni. Az online nyilvántartás nem közhiteles, nem a zálogtárgyakat tartja nyilván (reálfólium), hanem a zálogkötelezett személyéhez kapcsolja a bejegyzést (perszonálfólium), figyelemmel arra, hogy a jogok, követelések és a nem lajstromozott ingók természetüknél fogva csak korlátozottan tudnának megfelelni azoknak a követelményeknek, amelyeket egy dologi hatályú nyilvántartástól elvárhatnánk. A hitelbiztosítéki nyilvántartásról szóló szabályokat a 2013. évi CCXXI. törvény és az annak végrehajtását szabályozó, a hitelbiztosítéki nyilvántartás részletes szabályainak megállapításáról szóló 18/2014. (III. 13.) KIM rendelet tartalmazza. 
A lefoglalás ingók esetében elidegenítési és terhelési tilalommal jár, amelyet a Vht. 104. § (3) bekezdése mond ki. A lefoglalt ingóság elidegenítése, elzálogosítása, megsemmisítése, a végrehajtás alól való elvonása bűncselekményt valósít meg.

A végrehajtó azt követően, hogy megállapította, kinek áll fenn zálogjoga a lefoglalt zálogtárgyon, értesíti a zálogjogosultat, hogy a zálogjogból fakadó igényét - ha az alapügyben nem végrehajtást kérő - a végrehajtási eljárás során érvényesítheti, az erre vonatkozó kérelmét az értesítés kézhezvételétől számított 15 munkanapon belül kell a végrehajtónál bejelentenie. ${ }^{12}$

Ingatlan esetében 2009. január 1-jétől kezdődően nem a lefoglalást követően, hanem a becsérték közlésével egyidejüleg tájékoztatja a végrehajtó a zálogjogosultat a végrehajtási eljárásba történő bekapcsolódás lehetőségéröl a Vht. 140. $§$ (6) bekezdése alapján. ${ }^{13}$ Ennek az oka abban keresendő, hogy az ingatlan lefoglalására nem csupán a későbbi értékesítés céljából kerül sor, hanem azért, hogy a végrehajtás alapjául szolgáló vagyon biztosítva legyen, a végrehajtást kérő érdekei ne csorbuljanak. Amennyiben ugyanis a végrehajtási jog az ingatlan tulajdoni lapjára bejegyzésre kerül, az ingatlanra vonatkozóan jogot csak azzal a feltétellel lehet szerezni, hogy az a végrehajtást kérő végrehajtási jogát nem sérti, és a végrehajtás célját nem hiúsítja meg. ${ }^{14} \mathrm{Az}$ ingatlan lefoglalása - szemben az ingóságokkal - nem eredményez törvényen alapuló elidegenítési és terhelési tilalmat, a zálogtárgy tulajdonosa tehát az ingatlant visszterhesen is elidegenítheti, ezzel azonban nem teheti hátrányosabbá a végrehajtást kérő helyzetét. Amennyiben a foglalásra nem kerül sor, a zálogtárgy elidegenítése, megterhelése, mint a követelés fedezetének elvonása a végrehajtást akár meg is hiúsíthatja. A Vht. 138. §-a alapján az ingatlan lefoglalásáról a végrehajtónak igen szoros határidők betartása mellett kell intézkednie. Amennyiben a végrehajtást kérő a végrehajtható okiraton feltüntette az ingatlan adatait, a költségelöleget és az igazgatási díjat megfizette, a végrehajtó 3 munkanapon belül köteles az ingatlant lefoglalni. Ugyanígy jár el a végrehajtó, ha az ingatlan-nyilvántartás adatait beszerezte, és a végrehajtást kérő nem ellenezte az ingatlan lefoglalását. Sok esetben a lefoglalást követően a követelés megtérül, és nem kerül sor az ingatlan árverésre bocsátására, ezért a becsértékközlést megelőzően indokolatlan lenne a zálogjogosult végrehajtásba történő bekapcsolódása. Ezzel az adós érdekei is védelem alatt állnak, hiszen a bekapcsolódást megelőzően a végrehajtás alacsonyabb követelésösszeg behajtása iránt folyik. Az ingatlan becsértékének megállapítására azonban már egyértelműen az ingatlan későbbi árverésre bocsátása céljából kerül sor, ezért ekkor indokolt a zálogjogosult tájékoztatása bekapcsolódási lehetőségéről.

A bekapcsolódásról szóló eljárási szabályok a Vht. „Ingóvégrehajtás” címü fejezetében találhatók, azonban az ingatlanokra is irányadók.

A Vht. az ingón és ingatlanon alapított zálogjog jogosultjának lehetővé teszi a végrehajtási eljárásba történő bekapcsolódást, és külön rendezi a kielégítési sorrendben elfoglalt helyét, azonban nem szól a jogon és követelésen alapított zálogjog

\footnotetext{
12 Vht. 114. $§(2)$ bekezdés.

13 Pestovics llona: Bírósági végrehajtás. Novissima, Budapest, 2010, 185.

14 Vht. 138. $§(6)$ bekezdés.
} 
jogosultjáról. A Vht. 4. § (1) bekezdése ugyan egyértelművé teszi, hogy jog és követelés lefoglalására, végrehajtás alá vonására sor kerülhet, azonban kérdéses, hogy az ilyen speciális zálogtárgyon alapított zálogjog védelme, a zálogjogosult végrehajtási eljárásba való bekapcsolódása lehetséges-e, ha igen, akkor mely szabályok alapján, és hogyan alakul a kielégítési sorrendbeli helyzete. ${ }^{15}$

Általánosan elterjedt gyakorlat, hogy a végrehajtó egymáshoz csatolt ügyek esetén csupán az egyik ügyben hívja fel a zálogjogosultat a bekapcsolódásra, és a bíróság is ebben az ügyben engedélyezi, vagy éppen utasítja el a bekapcsolódás iránti kérelmet, nem pedig egyenként valamennyi ügyben. Ez kérdéseket vethet fel ingatlan esetén, ahol nem kizárt, hogy a végrehajtási jog bejegyzését követően sor kerüljön zálogjog alapítására, és ahol a zálogjogosult felhívására csak a zálogtárgy lefoglalását követően, a becsérték közlésével egyidejüleg kerül sor. A bekapcsolódás iránti kérelmet ugyanis a bíróság az alapügy tekintetében bírálja el, ezért, ha a zálogjog bejegyzése későbbi, mint az alapügyben bejegyzett végrehajtási jog, a kérelmet elutasítja, mivel a zálogjoggal biztosított követelés vonatkozásában a kielégítési jog nem nyílt meg. Ha pedig a zálogjog bejegyzése korábbi, akkor a bekapcsolódás engedélyezhető. lly módon elöfordulhat, hogy az alapügyben a bíróság elutasítja a bekapcsolódást, miközben a csatolt ügyben lehetőség lenne rá, hisz abban a végrehajtási jog nem elöbb, hanem később került bejegyzésre, mint a zálogjog. A bekapcsolódás tehát attól függ, melyik ügy az alapügy, azaz melyik ügyben bocsátja ki a felhívást a végrehajtó.

Egyes vélemények szerint ez a gyakorlat nem megfelelő: mindegyik végrehajtási ügyben egyenként kellene dönteni arról, hogy a bekapcsolódás feltételei fennállnak-e, hiszen különböző végrehajtást kérőkről van szó. Ez az elvi álláspont azonban számos problémát vet fel. Ebben az esetben ugyanis a zálogjogosultnak valamennyi csatolt végrehajtási ügyben is bekapcsolódás iránti kérelmet kellene előterjesztenie, és az illetéket valamennyi ügyben le kellene rónia, hiszen külön kérelmekröl van szó. Az illeték összege azonban ezzel megsokszorozódna, amely különösen hátrányos az illetéket előlegező zálogjogosultra és az azt viselő adósra nézve. További nehézséget jelenthet, ha a bekapcsolódási kérelmekröl különböző döntés születik. Míg az egyikben a bíróság megengedi a bekapcsolódást, előfordulhat, hogy egy másikban nem, mert például az egyik fél vitatja a zálogjog alapját képező, nem közokiratba foglalt követelést, és a polgári perrendtartásról szóló 1952. évi III. törvény (Pp.) 386. §-a szerinti perben a bíróság a keresetet elutasítja. Ezenkívül ez a fajta eljárás komoly leterheltséget jelentene a végrehajtók és a bíróságok számára is.

A Vht. 114/A. § (11) bekezdése sem hívható segítségül, mivel eszerint a bekapcsolódás hatálya csak azokra a végrehajtási eljárásokra terjed ki, amelyekben a zálogtárgy lefoglalására a bekapcsolódást követően került sor.

E körben indokolt a Vht. módosítása. Megoldás lehet, hogy a végrehajtó abban az ügyben hívja fel a zálogjogosultat a bekapcsolódásra, amelyben utoljára került sor a végrehajtási jog bejegyzésére. Ez a megoldás viszont ellenkezik a bírósági végrehajtási ügyvitelről és pénzkezelésről szóló 1/2002. (I. 17.) IM rendelet 24. § (3) bekezdésével, mely szerint az összes iratot a legkorábban érkezett végrehajtási ügy

15 KAPA Mátyás: Hitelezővédelem a bírósági végrehajtásban. Dialóg Campus, Budapest-Pécs, 2006, 141-142. 
száma alatt kell kezelni, amelyben feltehetően legkorábban került sor az ingatlan lefoglalására. Az is orvosolhatná a problémát, ha a Vht. 114/A. § (11) bekezdése változna akként, hogy a bekapcsolódás hatálya valamennyi olyan végrehajtási eljárásra kiterjedne, amelyben a zálogtárgyat a becsértékközlés, illetőleg a zálogjogosulti felhívás kibocsátásáig lefoglalták. Egyik esetben sem érné hátrány a zálogjogot megelőző végrehajtási jog jogosultját, a Vht. 170. § (3) bekezdése ugyanis kimondja, hogy e tekintetben nem lenne kielégítési elsőbbsége a zálogjogosultnak. A kielégítési sorrend pedig ugyanúgy alakulna, mintha minden egyes végrehajtási eljárásba külön-külön kellene a zálogjogosultnak bekapcsolódnia.

Nehézséget jelent továbbá a gyakorlatban, hogy a végrehajtók egyetemleges adóstársak egymáshoz csatolt ügyeiben az adósok közös tulajdonában álló ingatlan becsértékének megállapítását és a bekapcsolódás lehetőségéről szóló felhívást egy intézkedéssel valósítják meg, azért, hogy az ingatlan 1/1 tulajdoni illetősége vonatkozásában kerüljön sor a becsérték megállapítására. A két adós ellen azonban két külön számon folyik a végrehajtási eljárás, és sok esetben a zálogjogosultnak csak az egyik adós tulajdoni illetőségén áll fenn zálogjoga. Tekintettel arra, hogy a bekapcsolódás abba a végrehajtási eljárásba engedélyezhető, amelyben a felhívás kiadásra került, mindenképpen indokolt a végrehajtónak a becsértéket, illetve a bekapcsolódásra történő felhívást adósonként, külön kiadni, hiszen az egyik adós tulajdoni illetőségén fennálló zálogjog jogosultja nem kapcsolódhat be a másik adós ellen folyó végrehajtási eljárásba.

\section{A bekapcsolódásra jogosultak köre}

A Vht. 114. $\S(1)$ bekezdése és a 140. $§(6)$ bekezdése szerint azt a zálogjogosultat kell tájékoztatni a bekapcsolódás lehetőségéröl, aki az alapügyben nem végrehajtást kérö. ${ }^{16}$

A végrehajtók gyakorlata, hogy a nyilvántartásba bejegyzett valamennyi zálogjog jogosultját értesítik a bekapcsolódás lehetőségéről, így a végrehajtást kérőt is, ha zálogjoggal bír a lefoglalt zálogtárgyon. A bírói gyakorlat alapján az alapügyben eljárt végrehajtást kérő - mint zálogjogosult - végrehajtási eljárásba történő bekapcsolódásának engedélyezése nem kizárt, ha zálogjoga más követelés vonatkozásában áll fenn a zálogtárgyon, mint amit az alapeljárásban érvényesíteni kíván. A bekapcsolódás elmaradása esetén ugyanis a zálogtárgy értékesítése során más végrehajtást kérők, illetve zálogjogosultak kielégítést nyerhetnek, míg a végrehajtást

16 Vht. 114. $\S(1)$ bekezdés: A végrehajtó a foglalás után, illetve a lefoglalt vízi, légi jármű lajstromát vezető szervezet 103/A. § (2) bekezdése szerinti tájékoztatásának kézhezvételét követően haladéktalanul értesíti az ingóság lefoglalásáról azt, akiről valószínűsithető, hogy a lefoglalt ingóságon zálogjoga áll fenn. Így jár el a végrehajtó a hitelbiztosítéki nyilvántartás és a zálogjogi nyilvántartás adatainak beszerzését követően is. Vht. 140. $\S(6)$ bekezdés: A végrehajtó a becsérték közlésével egyidejüleg tájékoztatja a zálogjogosultat arról, hogy a zálogjogból fakadó igényét - ha az alapügyben nem végrehajtást kérő - végrehajtási eljárás során érvényesítheti, és az erre vonatkozó kérelmét az értesítés kézhezvételét követő 15 munkanapon belül kell bejelentenie a végrehajtónál. A végrehajtó a kérelmet haladéktalanul, de legkésőbb annak kézhezvételét követő munkanapon továbbítja a végrehajtást foganatosító bíróságnak. 
kérő egyéb - nem a megindított végrehajtásban érvényesíteni kívánt - követelése biztosítékául bejegyzett zálogjoga megszünhet. Helyesebb volna ezért a szabályozást úgy pontosítani, hogy az nem a végrehajtást kérőt mint zálogjogosultat zárná ki az értesítendők köréböl, hanem a kizárást az alapügyben érvényesített követelés tekintetében fogalmazná meg, vagy célszerü lenne a törvényszöveget kiegészíteni azzal, hogy azt a zálogjogosultat kell tájékoztatni a bekapcsolódás lehetőségéröl, aki az alapügyben nem végrehajtást kérő, kivéve, ha zálogjoga nem a végrehajtható okiratban foglalt követelés biztositására áll fenn. Ha a zálogjogosult részben vagy egészben azt a követelést kívánja a bekapcsolódás folytán érvényesíteni, mint amit az alapeljárásban, a bíróságnak ebben a részében a kérelmét el kell utasítani a kettős végrehajtás elkerülése miatt.

Jellemzö, hogy az önálló zálogjogot átruházhatósága miatt - annak ellenére, hogy a zálogjog járulékossága alóli kivételnek tekinthető - valamely követelés biztosítása céljából alapítják. A zálogjog átruházása esetén a hitelező és a zálogjog jogosultjának személye eltér egymástól. Az önáló zálogjog jogosultja abban az esetben is érvényesítheti bekapcsolódás iránti igényét, ha a végrehajtást a hitelező indította (az önálló zálogjoggal biztosított) követelése behajtása iránt. Az önálló zálogjogra ugyanis úgy kell tekinteni, mint amelyik önálósult az alapul fekvő követeléstöl. A zálogjog jogosultja ezért nem zárható el attól, hogy maga is a végrehajtás részese legyen, ellenkező esetben elöfordulhat, hogy zálogjoga elenyészik. A bekapcsolódás engedélyezése esetén természetesen fennáll a kettős végrehajtás veszélye, amely ellen az adós végrehajtás megszüntetése, illetve korlátozása iránt indított perben védekezhet.

Az új Ptk. az önálló zálogjogot eltörli, és helyette bevezeti a különvált zálogjogot. ${ }^{17}$ A különvált zálogjogot megszerzőnek a Ptk. 5:100. § (4) bekezdése alapján az eredeti zálogjogosult (jelen esetben végrehajtást kérő) érdekében kell eljárnia, valójában az eredeti zálogjogosult törvényes képviselöjének szerepét tölti be, és nem illeti meg zálogjog az eredeti zálogjogosulttal szembeni követelése biztosítékaként, a zálogjog a zálogkötelezett és a különvált zálogjog jogosultja között áll fenn. A különvált zálogjogosult zálogjoga tehát az eredeti, a zálogkötelezett és az eredeti zálogjogosult között létrejött követelés biztosítékául szolgál. Erre tekintettel az eredeti zálogjogosult által ezen követelés behajtása iránt indított végrehajtási eljárásba a különvált zálogjog jogosultja nem kapcsolódhat be, hiszen bekapcsolódása esetén ugyanannak a követelésnek a kétszeres végrehajtására kerülne sor, amelyet a Vht.

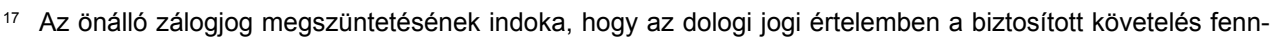
állására és mértékére tekintet nélkül biztosít kielégítési jogot a zálogjogosultnak. Annak a lehetősége, hogy a zálogjogosult dologi jogilag többet megtehet, mint amire kötelmi jogilag jogosult, ellentétes azzal a jogpolitikai céllal, amely a fiduciárius biztosítékokat háttérbe kívánja szorítani. Az önálló zálogjogot hazánkban a jelzálogbankok használták, elsősorban lakáshitelek refinanszírozása körében. A refinanszírozás azonban valójában nem igényli az önálló zálogjogot. Lásd Vékás Lajos (szerk.): Szakértői javaslat az új Polgári Törvénykönyv tervezetéhez. CompLex, Budapest, 2008, 657. A jogalkotó az önálló zálogjogot ezért eltörölte, és megalkotta a különvált zálogjogot. Ez az új zálogjogi forma alkalmas lehet arra, hogy a kereskedelmi bankok és jelzálog-hitelintézetek a korábbi gyakorlatnak megfelelöen folytathassák finanszírozási és refinanszírozási tevékenységüket. Lásd TÓтH Gábor Márton: A különvált zálogjog kérdéseiröl. THEMIS elektronikus folyóirat, 2014. december, http://www.ajk.elte.hu/file/THEMIS_2014_dec.pdf (2015. 10. 02.). 
tilalmaz. A zálogjog járulékossága kizárja, hogy a követelés és az azt biztosító zálogjog egy eljárásban történő érvényesítésére kerüljön sor. Ezért álláspontom szerint a különvált zálogjog jogosultjának bekapcsolódási kérelmét a bíróságnak a fentiek alapján el kell utasítania.

\section{A bekapcsolódás iránti kérelem}

A bekapcsolódás iránti kérelem végrehajtás elrendelése iránti kérelemnek minősül, hiszen egy új végrehajtást kérő, egy új követelés kielégítése céljából lép be a már folyó végrehajtásba. A bírósági végrehajtási ügyvitelről és pénzkezelésről szóló 1/2002. (I. 17.) IM rendelet (Vüsz.) 7. § (2) bekezdése is végrehajtás elrendelése iránti kérelemnek nevezi a zálogjogosult végrehajtási eljárásba történő bekapcsolódása iránti kérelmét. A Vht. azonban a 10. §-ban a végrehajtható okiratok között a bekapcsolódást engedélyező végzést nem tünteti fel, hiszen nem egy önálló, hanem egy járulékos végrehajtási eljárásról van szó, amely függő viszonyban van az alapvégrehajtással. Ez esetben a végrehajtás Vht. 13. §-ában foglalt általános feltételei is speciális módon érvényesülnek. Nem szükséges ugyanis a bekapcsolódáshoz az, hogy a zálogjoggal biztosított követelés adósa a teljesítéssel késedelembe essen, azaz a teljesitési határidő elteljen. A zálogtárgy lefoglalásának ténye a Vht. 114/A. $\S(2)$ bekezdése szerint a követelést önmagában lejárttá teszi. ${ }^{18}$ Ez természetesen nem jelenti azt, hogy a követelés a bekapcsolódással érintett végrehajtási eljáráson kívül is lejártnak tekinthető, azaz a zálogjogosult önállóan nem indíthat végrehajtást igénye érvényesítésére, ha követelése nem esedékes. ${ }^{19}$

Ingók esetében a végrehajtó foglalási jegyzőkönyv kiállitásával foglal. ${ }^{20} \mathrm{~A}$ Vht. egyes speciális ingóságok, például nemesfémek, értékpapír, gépjármü, üzletrész foglalására eltérő szabályokat állapít meg. ${ }^{21}$ Ingatlan foglalása a végrehajtási jog ingatlan-nyilvántartásba történő bejegyzése által valósul meg. ${ }^{22}$

A bekapcsolódás engedélyezése iránti kérelmet a végrehajtást foganatositó végrehajtónál kell benyújtani 3 példányban az értesítés kézhezvételétől számított 15 munkanapon belül a végrehajtást foganatositó bírósághoz címezve. Eltérő a gyakorlat a tekintetben, ha a kérelmet nem a végrehajtónál, hanem a bíróságnál terjeszti elő a zálogjogosult. Egyes bíróságok a kérelmet ilyenkor is befogadják, és a végrehajtási iratok becsatolására hívják fel a végrehajtót, mások a kérelmet továbbítják a végrehajtó felé, és amennyiben az 15 munkanapon túl érkezik a végrehajtóhoz, a kérelmet elkésettség miatt érdemi vizsgálat nélkül elutasítják. Bár utóbbi gyakorlat a törvény rendelkezésének jobban megfelel, véleményem szerint méltánytalan a zálogjogosultra nézve, hiszen ez esetben a bíróság gyorsaságán múlik, hogy a kérelem határidőben megérkezik-e a végrehajtóhoz.

18 BDT.2003.858.

19 CompLex Jogtár, Nagykommentár a bírósági végrehajtásról szóló 1994. évi LIII. törvényhez, 114/A. §-hoz füzött magyarázat.

20 Vht. 88. §.

21 Vht. 98-103/D. §.

22 Vht. 138. $\S(2)$ bekezdés. 
Szintén megosztott a gyakorlat abban, hogy a 15 munkanapos határidőt anyagi, illetve eljárási jogi jellegünek kell-e tekinteni, azaz a kérelemnek meg kell-e érkeznie a végrehajtóhoz a 15. munkanapon, vagy elégséges, ha aznap postára adják. Az eljárásjogi határidő mellett voksolók azzal érvelnek, hogy a Vht. kifejezetten nem rendelkezik arról, hogy a határidő jogvesztő, vagy a határidő elmulasztásának jogkövetkezményei igazolási kérelemmel orvosolhatók. A bírói gyakorlat eltérését jól mutatja, hogy hosszú ideig a Budapest Környéki Törvényszék másodfokú tanácsainak egyöntetű álláspontja volt, hogy a határidő anyagi joginak tekintendő. Jelenleg a Budapest Környéki Törvényszéken és a Fővárosi Törvényszéken is eljárásjogi határidőnek tekintik.

A Vht. 114. § (2) bekezdése, valamint a 140. § (6) bekezdése alapján a végrehajtó a kérelmet annak kézhezvételét követő munkanapon továbbítja a végrehajtást foganatosító bíróságnak. A kérelemben a zálogjogosultnak meg kell jelölnie, hogy melyik végrehajtási eljárásba kíván bekapcsolódni, és mely vagyontárgy milyen tulajdoni illetősége tekintetében. Elő kell adnia követelése mértékét, ezen belül részletezve a tőkekövetelés, az ügyleti és késedelmi kamat összegét, azt, hogy a kamatot mely időponttól kezdődően, meddig kéri, illetve meg kell jelölnie az egyéb járulékok ${ }^{23}$ összegét is. Igazolnia kell, hogy zálogjoga áll fenn a vagyontárgyon, így ingatlan esetén mellékelnie kell az ingatlan tulajdoni lapját. Ezenkívül csatolnia kell a követelés alapjául szolgáló jogviszonnyal kapcsolatos iratokat, illetve - ha költségkedvezményben nem részesül - az illetéket le kell rónia.

A bírói gyakorlat az illeték alapjának megállapítása tekintetében nem egységes. Egyes álláspont szerint a bekapcsolódás iránti kérelem illetékmentes beadvány az illetékekről szóló 1990. évi CXIII. törvény (Itv.) 57 . § (1) bekezdés m) pontja alapján, mely kimondja, hogy illetékmentes polgári ügyekben az önálló bírósági végrehajtónak az általa lefolytatott bírósági végrehajtási eljárással összefüggésben kezdeményezett eljárása. Ez egyértelmúen cáfolható a Vht. 114/A. § (10) bekezdése alapján, e szakasz szerint ugyanis a végrehajtási eljárásba bekapcsolódó zálogjogosultra a végrehajtási eljárás illetékének és egyéb költségeinek előlegezése és viselése tekintetében a végrehajtást kérőre irányadó jogszabályokat kell alkalmazni, ezenkívül ezt az eljárást nem a végrehajtó, hanem a zálogjogosult kezdeményezi.

Az illeték alapja a kérelemben megjelölt követelés járulékok és költségek nélkül számított értéke vagy a zálogtárgy értéke, attól függően, hogy melyik az alacsonyabb. A zálogjogosult kérheti ugyan a követelés erejéig történő bekapcsolódást, azonban amennyiben a zálogtárgy értéke alacsonyabb annál, a zálogjogosult úgyis csak a zálogtárgyból, annak értéke erejéig szerezhet kielégítést. A gyakorlatban felmerült, hogy amennyiben az adós, illetve a végrehajtást kérő csak részben ismerte el a zálogjogosult követelését, és a zálogjogosult nyilatkozata alapján az elismert rész erejéig történik a végrehajtási eljárásba történő bekapcsolódás, az az összeg lesz az illeték alapja, amelyre a bíróság a bekapcsolódást engedélyezte. Álláspon-

23 A zálogjogosult az eljárás illetékét és a jogi képviselő díját is igényelheti. A jogi képviselők díjazásának szabályait a bírósági végrehajtási eljárásban közremüködő jogi képviselő díjazásáról szóló 12/1994. (IX. 8.) IM rendelet állapítja meg. A rendelet alapján járó díjak jóval alacsonyabbak, mint a bírósági eljárásban megállapítható ügyvédi költségekről szóló 32/2003. (VIII. 22.) IM rendelet szerinti díjazás. 
tom szerint ez az érvelés azért téves, mert az Itv. 3 . § (4) bekezdése szerint az eljárási illetékkötelezettség az eljárás megindítása iránti kérelem előterjesztésekor keletkezik, ezért nem lehet az alapja a zálogjogosult később módosított követelése. Az Itv. 41. § (2) bekezdése alapján pedig az eljárás tárgyának értéke utólagos leszállítása az illetékalapot nem érinti.

A Civilisztikai Kollégiumvezetők 2012. október 19-én tartott országos tanácskozásán a kollégiumvezetők egyetértettek abban, hogy a zálogjogosult bekapcsolódása iránti kérelem tárgyának illetéke nem határozható meg az Itv. 39. § (3) bekezdésére tekintettel. Ettől eltérően a Civilisztikai Kollégiumvezetők 2013. május 8. és 10. között tartott országos tanácskozása már úgy foglalt állást, hogy az eljárás tárgyának, így az illetéknek a mértéke a zálogjogosult követelése alapján meghatározható, az más végrehajtás elrendelése iránti kérelem illetékéhez hasonlóan az Itv. 4. § (1) bekezdés d) pontja alapján 1\%, de legalább 5000 forint, legfeljebb 350000 forint.

Nehézséget okoz a devizában meghatározott követelések illetékének megállapítása, mivel az illeték alapját forintban kell meghatározni, és a devizában megjelölt értéket a kérelem előterjesztésekor, azaz annak bíróságra érkezése napján a Magyar Nemzeti Bank hivatalos devizaárfolyamának alapulvételével kell forintra átszámolni. ${ }^{24} \mathrm{~A}$ devizaárfolyamok naponkénti változása miatt azonban a kérelmező a kérelem postára adásának napján nyilvánvalóan nem tudhatja előre, hogy mekkora lesz a devizaárfolyam a kérelem bíróságra érkezésekor. Ezért bevett gyakorlat, hogy az illeték összegét a bíróság a bekapcsolódás iránti kérelem postára adása, illetve a személyes beadás napján érvényes árfolyamon számítja ki.

A hitelező követelése behajtása céljából kérheti végrehajtható okirat kiállítását, és igényét bekapcsolódás iránti eljárásban is érvényesítheti. A két eljárás egymástól elkülönül, hiszen az egyikben az adós teljes vagyonára végrehajtás vezethető, míg a járulékos bekapcsolódás iránti eljárás a zálogjogosult kielégítési elsőbbségének védelmét célozza, ahol követelése kielégítésére csak a zálogtárgy szolgál, és az eljárás az alapvégrehajtás befejeződésével megszünik. Ezért - bár mindkét eljárás ugyanazon követelés kielégítését célozza - az illeték lerovása szempontjából két külön eljárásnak minősülnek, az egyik eljárás illetékét a másikba nem lehet beszámítani. ${ }^{25}$

A zálogjogosult személyében az anyagi jogi szabályok alapján bekövetkezett jogutódlás esetén a jogutódra a törvény erejénél fogva száll át a zálogjog. Ezért a zálogjogosult jogutódlásának megállapításához és a végrehajtási eljárásba történő bekapcsolódás engedélyezéséhez nem kell igazolni azt, hogy a jogutód be van jegyezve a zálogjogi nyilvántartásba vagy ingatlan-nyilvántartásba, mivel a bejegyzés az alapításnak és nem az átszállásnak a feltétele. A jogutódot azonban a jogosult személyében bekövetkezett változásra nézve bejelentési kötelezettség terheli, amely elmulasztásából eredő hátrányt másra nem háríthatja. Ha a nyilvántartásba a jogutód személye nem kerül bejegyzésre, a végrehajtó csupán a zálogjogosult jogelődjét tudja felhívni a bekapcsolódás lehetőségére. Ha a jogelőd az értesítésről nem tájékoztatja a jogutódot, és a jogutód gondos eljárása mellett sem tudhatott a

\footnotetext{
${ }^{24}$ Az illetékekröl szóló 1990. évi XCIII. törvény (Itv.) 71. § (1) és (2) bekezdés.

25 BDT.2009.2055.
} 
zálogjogával terhelt zálogtárgy lefoglalásáról, illetve a bekapcsolódás lehetőségéröl, a bekapcsolódási kérelem késedelmes előterjesztése miatt a Pp. szabályai alapján igazolással élhet.

Ha a közhiteles ingatlan-nyilvántartásba már a jogutód személye van bejegyezve, álláspontom szerint a jogutódlás megállapítására külön végzéssel nincs szükség, hiszen az ingatlan-nyilvántartási bejegyzésre csak a jogutódlás megfelelö igazolása esetén kerülhetett sor.

\section{A végrehajtás felfüggesztése}

A zálogjogosult által előterjesztett kérelem beérkezését követő 3 munkanapon belül a bíróság a végrehajtást felfüggeszti, amelyröl a végrehajtót azonnal értesíti, egyúttal részére a felfüggesztést elrendelő végzést megküldi. ${ }^{26} \mathrm{~A}$ soron kívüli eljárásra tekintettel a végzést célszerü fax útján is megküldeni a végrehajtó részére. A felfüggesztést akkor is el kell rendelni, ha arra vonatkozóan a zálogjogosult kérelmet nem terjeszt elö, mivel az a Vht. 48. § (2) bekezdése alapján kötelező. ${ }^{27}$

Eltérő a gyakorlatban annak megítélése, hogy hiányos kérelem esetén a 3 munkanapos határidő mikor kezdődik. A többségi bírói gyakorlat szerint ${ }^{28}$ a határidőt attól az időponttól kell számítani, amikor a bekapcsolódás iránti kérelem hiányait pótolták, ${ }^{29}$ figyelemmel arra, hogy csak a hiánytalan kérelem vált ki joghatályt. ${ }^{30}$ Más álláspont szerint azonban a törvény egyértelmüen meghatározza, hogy a végrehajtás felfüggesztését soron kívül, a kérelem bíróságra érkezésétöl számított 3 munkanapon belül el kell rendelni, és a határidő nem tehető függővé attól, hogy a kérelem hiányosan érkezik. A hiányok pótlása - akár kisebb hiányosság esetén is hosszabb időt is igénybe vehet, a felfüggesztés elmaradása ezért a zálogjogosultat hátrányosan érintheti.

A felfüggesztés hatálya nem terjed ki a teljes végrehajtási eljárásra, csak a zálogtárgy árveréséről történő értékesítéséröl szóló hirdetmény elkészítésére, illetve a zálogtárgy értékesítésére, ide nem értve a romlandó dolgok értékesítését. ${ }^{31}$

A felfüggesztést elrendelő végzés ellen a végrehajtást kérő, az adós és a zálogjogosult fellebbezhet. A felfüggesztés hatálya az azt elrendelő határozat meghozatalának időpontjában áll be, ${ }^{32}$ a fellebbezésnek nincsen halasztó hatálya.

26 Vht. 48. § (2) bekezdés.

27 Ha a zálogjogosult a 114/A. § (1) bekezdése, illetve a 140. § (6) bekezdése szerinti kérelmet terjesztett elő, a kérelem beérkezését követő 3 munkanapon belül a bíróság a végrehajtást felfüggeszti.

28 Pestovics: i. m., 153.

29 SıMON Károly László: $A$ végrehajtás foganatositásának gyakorlati problémái a birósági gyakorlat tükrében. Jegyzet, átdolgozott kiadás, lezárva 2013. április 15., 11.

30 BALOGH: i. m., 296.

31 Vht. 50. § (4) bekezdés.

32 Vht. 50. $\S(1)$ bekezdés. 


\section{A vitatás lehetösége}

A bíróság a zálogjogosult kérelmét kézbesíti az adósnak és a végrehajtást kérőnek azzal a felhívással, hogy a kézhezvételtöl számított 8 nap alatt nyilatkozzanak arról, hogy a zálogjoggal biztosított követelés jogalapját - önálló zálogjog esetén a jogalapot - és összegszerüségét elismerik-e, illetöleg milyen összegben ismerik el.

Ha a határidő alatt az adós vagy a végrehajtást kérő a jogalapot vagy az öszszegszerüséget vitatja, és állitását valószínűsítette, a kérelmet a bíróság végzéssel elutasítja. Ebben az esetben a zálogjogosult a Pp. 386. §-a szerinti végrehajtási eljárásba történő bekapcsolódás engedélyezése iránti pert indíthat zálogjogból fakadó igénye érvényesítése végett.

A vitatásra érdemben csak akkor van lehetöség, ha a jogalapot és az összegszerüséget nem közokiratba foglalták. Az esetek döntő többségében azonban a követelés alapjául szolgáló okirat közokirat, így a vitatás lehetősége csupán formális. Elöfordulhat, hogy az összegszerüséget vitatják, és a kérelemben foglalttól eltérő összegben ismerik el, ez esetben a bíróságnak tájékoztatni kell a zálogjogosultat, hogy ezen összeg tekintetében is kérheti a bekapcsolódást. Amennyiben a zálogjogosult az adós vagy a végrehajtást kérő által megjelölt összegben kéri a bekapcsolódást, a jogalap és az összegszerüség utóbbi összeg tekintetében már nem tekinthetö vitatottnak. Közokiratba foglalt követeléseket nem lehet vitatni, azonban amennyiben valamelyik fél kérelemre tett nyilatkozatára a zálogjogosult mégis módosítaná a kérelmét, ehhez képest kell a bekapcsolódását engedélyezni.

A nem közokiratba foglalt követelések vitatása esetén a vitatást valószínüsíteni kell. A törvény tehát nem követeli meg az állítások igazolását, bizonyítását, azonban elvárja azok „hihetővé tételét” abból a célból, hogy ezáltal a bíróság a zálogjogosult bekapcsolódás iránti kérelmét elutasítsa. Ehhez a legtöbb esetben feltehetően nem elegendő a puszta állitás, hanem valamely okirati bizonyíték csatolása is szükséges. A kérelem elutasítása esetén a zálogjogosult perrel érvényesítheti igényét, amelyben már állításait bizonyítania kell. A bizonyítási eljárás a végrehajtási nemperes eljárás kereteit meghaladná.

A közokiratba foglalt követelések vitatásával kapcsolatban általánosságban elmondható, hogy az esetek túlnyomó többségében a követelést a felek közokiratba foglalják, és a zálogjogot ingatlanra alapítják. A felek csekély számban vitatják a jogalapot vagy az összegszerüséget, és ehhez képest is elenyésző azon ügyek száma, ahol a zálogjogosult az adós vagy végrehajtást kérő vitatását - például teljesítésre hivatkozását - elfogadva, korábbi kérelmétől eltérően a vitató fél által megjelölt összegben kéri a bekapcsolódást. Ha a felek a jogalapot vagy összegszerüséget vitatják, azonban a zálogjogosult a követelését ennek hatására nem módosítja, a bíróságnak akkor is engedélyezni kell a bekapcsolódást, ha a vitató fél az állításait kétséget kizáró módon, okiratokkal igazolja. Nincs arra megfelelő indok, hogy a zálogjogosult perrel érvényesítse a zálogjogból eredő igényét, amikor a követelés jogalapját és összegszerüségét egyaránt közokiratba foglalták. ${ }^{33} \mathrm{Az}$ adós a védekezését végrehajtás megszüntetése vagy korlátozása iránti perben érvényesítheti.

33 BDT.2003. 858. 
Felmerül a kérdés, hogy miért szükséges megküldeni közokiratba foglalt követelések esetén a zálogjogosult kérelmét a feleknek, és miért nem lehet a kérelem alapján - felhívás nélkül - a bekapcsolódást engedélyezni. Vavroh Géza Alajos kifejti, hogy a közokiratot a közjegyző abban az esetben záradékolhatja, ha az tartalmazza a Vht. 23/C. $§(1)$ bekezdésében foglalt feltételeket, azaz „a szolgáltatásra és ellenszolgáltatásra irányuló vagy egyoldalú kötelezettségvállalást, a jogosult és a kötelezett nevét, a kötelezettség tárgyát, mennyiségét (összegét) és jogcímét, a teljesítés módját és határidejét". Azzal érvel, hogy az ingatlan-nyilvántartás szintén tartalmazza ezen adatokat. Így a jogosult és a kötelezett nevét, a biztosított követelés összegét, illetve a kamatot és más mellékszolgáltatást. A teljesítés határidejét nem tünteti fel, azonban szükségtelen is lenne, hiszen a zálogtárgy lefoglalása a követelést lejárttá teszi. Az ingatlan-nyilvántartás közhitelessége pedig megfelelő garanciát nyújt a visszaélések elkerülésére. Mindezek alapján tehát abban az esetben, ha a zálogtárgy ingatlan, a bíróság a zálogjogosult kérelmére minden további intézkedés nélkül engedélyezhetné a végrehajtási eljárásba történő bekapcsolódást, azaz az adós és a végrehajtást kérő vitatási lehetőségének kizárásával, méghozzá általános jelleggel, azaz nem csupán a közokiratba foglalt követelések esetén. ${ }^{34}$

Álláspontom szerint is célszerü lenne az eljárás gyorsítása a közokiratba foglalt követelések esetén. Megítélésem szerint azonban ezt nem az ingatlan-nyilvántartás közhitelessége alapozza meg, hanem az, hogy a követelés jogalapját és összegszerüségét közokiratba foglalták, amely teljesen bizonyítja az okirattal tanúsított adatok és tények valóságát, úgyszintén az okiratban foglalt nyilatkozat megtételét, valamint annak idejét és módját. Indokolt ezért ingók és ingatlanok esetén is közokiratba foglalt követelések esetén a vitatás lehetőségét mellőzni. Ahogyan a végrehajtási lap, illetve a záradék kiállítására is csupán a végrehajtást kérő egyoldalú nyilatkozata alapján kerül sor, úgy a bekapcsolódásról is a zálogjogosult egyoldalú kérelme alapján döntene a bíróság. A vitatás lehetősége csupán időhúzás, és a gyakorlatban nemigen kerül rá sor, a végrehajtást pedig - a felfüggesztés miatt - megakasztja.

Rendszeresen előfordul, hogy a zálogjogosultak eltérő pénznemben kérik a bekapcsolódást, mint ahogy az a nyilvántartásba be van jegyezve. Ez csak abban az esetben engedélyezhető, ha a zálogjog alapjául szolgáló szerződésben a felek a kérelemben meghatározott pénznemben állapodtak meg, hiszen az adós arra vállalt kötelezettséget.

\section{A bekapcsolódás engedélyezésének feltételei}

A zálogjogosult kielégítési jogát a bíróság megállapítja, ha

a) az adóssal szemben végrehajtási eljárás van folyamatban, az alapvégrehajtás sem ügyviteli szempontból, sem érdemben nem fejeződött be;

34 VAVROH Géza Alajos: A zálogjogosult végrehajtási eljárásba való bekapcsolódás iránti eljárás szabályozásáról, a végrehajtás megszüntetése és korlátozása iránti perekkel való összefüggéseiröl és gyakorlati megvalósulásáról. jogiforum.hu, 2012., internetes forrás: http://www.foe.hu/uploads/els\%C5\%91\%20publik\%C3\%A1ci\%C3\%B3\%20-\%20Vavroh\%20G\%C3\%A9za\%20Alajos.pdf (2015. 10. 02.). 
b) a zálogjogosult nem végrehajtást kérö, kivéve, ha zálogjoga nem a végrehajtható okiratban foglalt követelés biztosítására áll fenn;

c) a zálogtárgyat a végrehajtási eljárás során lefoglalták;

d) ha a zálogjoggal biztosított követelés jogalapja és összegszerüsége - önálló zálogjog esetén a jogalap és az összegszerüség - nem vitatott;

e) a zálogjogosult nem az adós hozzátartozója vagy olyan jogi személy, amelynek az adóssal való viszonyában többségi befolyás áll fenn, illetve a zálogjog alapítására a gazdálkodó szervezet és tagja között kerül sor.

A bekapcsolódást engedélyező végzés tartalmi elemeit a Vht. 114/A. § (3) bekezdése határozza meg.

\subsection{A bekapcsolódás járulékossága}

A bekapcsolódás egy már folyamatban lévő végrehajtási eljárásba történik a zálogtárgy végrehajtásának veszélye miatt. Kötődik az alapvégrehajtáshoz, azzal függő viszonyban van. Ezt fejezi ki a Vht. 114/A. § (12) bekezdése is, mely szerint a bekapcsolódással indult végrehajtás - ha a zálogjogosultnak a bekapcsolódással érintett költségei megtérültek - a végrehajtás (bekapcsolódással érintett több végrehajtás esetén valamennyi végrehajtás) befejeződésével megszűnik.

A bekapcsolódás járulékos jellegéböl következik, hogy amennyiben a zálogjogosult bekapcsolódási kérelmének előterjesztése előtt vagy azt követően, de még annak elbírálása előtt az eredeti végrehajtás bármely ok folytán érdemi vagy ügykezelési befejezéssel megszűnik, nincs helye a bekapcsolódás engedélyezésének. Az alapvégrehajtás érdemi befejezésének esetei a Vüsz. 33. §-ában (például végrehajtás megszüntetése), míg ügyviteli befejezésének esetei a 34. §-ban (például szünetelés) találhatók.

Megosztott a bírói gyakorlat, hogy mi a teendö abban az esetben, ha a szünetelő végrehajtásba kíván a zálogjogosult bekapcsolódni. Létezik olyan álláspont, miszerint ilyenkor el kell utasítani a kérelmet, mivel a Vüsz. szerint a szünetelés folytán befejezetté válik az ügy, befejezett ügybe pedig nem lehet bekapcsolódni. A végrehajtás azonban ilyen esetben nem fejeződött be, csupán a végrehajtónál jelentkezik ügyviteli befejezésként. Ezenkívül a bekapcsolódás iránti kérelem elöterjesztése határidőhöz kötött, ezért, ha utóbb folytatódik az alapvégrehajtás, a zálogjogosult már csak elkésetten tudná a kérelmét ismételten előterjeszteni. Nem helyeselhetö az a gyakorlat sem, amely az alapeljárás esetleges ügyviteli befejezése esetén a bekapcsolódási kérelmet érdemben elbírálja. Abban az esetben ugyanis, ha olyan eljárásba engedélyezi a bíróság a bekapcsolódást, amely szünetel, és utóbb az alapvégrehajtás megszünésére okot adó körülmény merül fel (például az adós részletfizetéssel a teljes tartozást kiegyenlíti), az adósnak meg kell fizetnie a zálogjogosult bekapcsolódással kapcsolatban felmerült költségeit (például illetéket, jogi képviselő diját) a Vht. 114/A. § (12) bekezdése alapján, amely igen méltánytalan az adósra nézve. Bár a bekapcsolódás iránti eljárásszünetelés időtartamának leteltéig történő felfüggesztésére a Vht. kifejezetten nem ad lehetőséget, mégis ez a gyakorlat helyeselhető. Így foglaltak állást a Civilisztikai Kollégiumvezetők 2012. 
október 18-án, valamint 2013. május 8-10. között tartott tanácskozásán résztvevők. Több megyében a Vht. 9. § alapján alkalmazandó Pp. 152. § (2) bekezdését hívják segítségül, annak ellenére, hogy nem előkérdésről van szó. Természetesen ilyenkor is 3 munkanapon belül rendelkezni kell a végrehajtás felfüggesztéséröl.

Ha a szünetelés elteltével az alapvégrehajtás folytatódik, a bekapcsolódás iránti kérelem tárgyában indult eljárást is folytatni kell, a kérelmet érdemben el kell bírálni. Amennyiben az alapvégrehajtás érdemben befejeződik, a bekapcsolódás iránti kérelmet érdemi vizsgálat nélkül el kell utasítani, és rendelkezni kell az Itv. 58. § (1) bekezdés f) pontja alapján az illeték 10\%-ra történő mérsékléséről, az ezt meghaladó lerótt illeték visszatérítéséröl, és az adóst kell kötelezni a mérsékelt illeték, valamint a zálogjogosult bekapcsolódási kérelem előterjesztésével felmerült egyéb költségei megfizetésére.

A bekapcsolódással indult végrehajtási eljárás járulékossága több kérdést is felvet a bekapcsolódás engedélyezését követően is. A Vht. 114/A. $\S(10)$ bekezdése alapján a bekapcsolódó zálogjogosultat a végrehajtási eljárás során olyan jogok illetik meg és olyan kötelezettségek terhelik, mint a végrehajtást kérőt. Nem egyértelmü a gyakorlat, hogy kérheti-e a zálogjogosult például az ingatlan árverését, ha a végrehajtást kérő nem kéri, és esetleg részletfizetésben állapodott meg az adóssal, amely miatt az alapvégrehajtás a bekapcsolódást követően szünetel. Az egyik - általam is helyeselt - nézet szerint a bekapcsolódás folytán indult eljárás járulékos, ezért anynyiban van létjogosultsága, amennyiben a zálogtárgy végrehajtási értékesítésének veszélye miatt gyakorolják, ezért, ha a végrehajtást kérő nem kéri az ingatlan árverését, vagy részletfizetésben állapodik meg az adóssal, a zálogjogosult nem jogosult az ingatlan árverését kérelmezni. Más álláspont alapján a Vht. 114/A. § (10) és (12) bekezdéséből következik, hogy a bekapcsolódással indult végrehajtás csak az alapvégrehajtás érdemi befejeződése esetén szűnik meg, egyebekben a zálogjogosult gyakorolhatja a végrehajtást kérő jogait, ezért az alapvégrehajtás szünetelésére, illetve a végrehajtást kérőre tekintet nélkül kérheti az ingatlan árverését.

\subsection{A zálogjog-bejegyzés idejének jelentősége}

A lefoglalt ingóságon elidegenítési és terhelési tilalom áll fenn, ezért a zálogtárgyra a foglalását követően zálogjogot alapítani jogszerüen nem lehet. Ingatlan esetében azonban a foglalást követően zálogjog még alapitható azzal, hogy a Vht. 138. § (6) bekezdése szerint a lefoglalt ingatlanra vonatkozóan jogot csak azzal a feltétellel lehet szerezni, hogy az a végrehajtást kérő végrehajtási jogát nem sérti, és a végrehajtás célját nem hiúsítja meg.

Ha a zálogjogosult zálogjogának bejegyzésére a végrehajtási jog bejegyzését, azaz a foglalást követően került sor, a bekapcsolódási kérelmet el kell utasítani, hiszen ez esetben a lefoglalás időpontjában nem volt olyan zálogjoggal biztosított követelés, amely tekintetében a kielégítési jog megnyílhatott volna. 


\subsection{Az összefonódás}

A fedezetelvonó ügyletek kiszürése érdekében a jogalkotó a Vht. 114/A. § (2) bekezdésében úgy rendelkezett, hogy a kielégítési jog megnyíltát nem lehet megállapítani, ha a zálogjogosult az adós hozzátartozója vagy olyan jogi személy, akinek az adóssal való viszonyában többségi befolyás áll fenn, illetve a zálogjog alapítására a gazdálkodó szervezet és tagja között került sor. Ilyenkor a fedezetelvonás vélelme érvényesül. ${ }^{35,36}$

\subsection{A bekapcsolódás iránti kérelmet elutasító végzés}

Ha nem közokiratba foglalt követelés esetén valamelyik fél a jogalapot vagy öszszegszerüséget vitatja, és állítását valószínüsíti, a kérelmet el kell utasítani. ${ }^{37}$

A végzés rendelkező részében vagy indokolásában tájékoztatni kell a zálogjogosultat a Vht. 114/A. § (5) bekezdésére, hogy igényét külön perben érvényesítheti. Indokolt továbbá arra is felhívni a figyelmét, hogy amennyiben a keresetet 8 napon belül benyújtja, és azt igazolja, a végrehajtás felfüggesztésének hatálya fennmarad. ${ }^{38}$

A bíróság a bekapcsolódás iránti kérelmet abban az esetben is elutasítja, ha az érdemi vizsgálatra nem alkalmas, és a hiányokat a jogi képviselő nélkül eljáró fél nem pótolta. Szintén a kérelem érdemi vizsgálat nélkül történő elutasításának van helye, ha a bekapcsolódás iránti kérelem előterjesztését megelőzően vagy azt követően, de annak elbírálása előtt az alapvégrehajtás érdemi befejezés folytán megszünik, ez esetben ugyanis nincs folyamatban végrehajtási eljárás, melybe az érdekelt bekapcsolódhatna. A kérelem érdemi vizsgálat nélkül való elutasítása esetén a korábban már kifejtettek szerint az illeték mérséklésének van helye.

Jelentőséggel bír, hogy a bíróság mely rendelkezés alapján utasítja el érdemi vizsgálat nélkül a hiánypótlási felhívás ellenére is hiányosan benyújtott, valamint a jogi képviselő által hiányosan előterjesztett kérelmet.

Nem helyeselhető a Vht. 12. § (2) bekezdésének alkalmazása, mely alapján a jogi képviselő hiányos kérelmét érdemi vizsgálat nélkül el kell utasítani, ugyanis a Vht. 12. §-ban foglalt szabályok kifejezetten a 10. §-ban foglalt végrehajtható okiratok esetén mérvadók, a bekapcsolódást engedélyező végzés pedig ezek között nevesítve nincsen. Ezenkívül a zálogjogosult által benyújtott újabb kérelem esetén a korábbi kérelem jogi hatályai nem maradnak fenn, így az feltehetően már elkésetten fog megérkezni a bíróságra, figyelemmel arra, hogy annak előterjesztésére a zálogjogosultnak mindösszesen 15 munkanapja van a végrehajtói felhívástól számítva.

35 Pestovics: i. m., 151.

36 A hozzátartozó fogalmát a Vht. 9. §-ában foglalt utaló szabálya alapján háttérjogszabályként alkalmazandó Pp. 13. $§(2)$ bekezdése határozza meg. A gazdálkodó szervezet fogalmát a Pp. 2014. március 15. napjától hatályba lépett módosított 396. §-a, a többségi befolyás fogalmát az új Ptk 8:2. §-a tartalmazza.

37 Vht. 114/A. § (5) bekezdés

38 Vht. 114/A. $§(7)$ bekezdés. 
A bekapcsolódási kérelem hiányai esetén többen a Vht. 9. §-a alapján alkalmazandó Pp. 95. § (2) bekezdésének felhívásával rendelnek el hiánypótlást abban az esetben is, ha a kérelmet jogi képviselö nyújtotta be.

Meglátásom szerint azonban a jogalkotó a végrehajtás elrendelése során érvényesíteni kívánta azt az elvet, hogy a jogi képviselővel eljáró fél hiányos kérelmét hiánypótlási felhívás kiadását mellőzve, érdemi vizsgálat nélkül el kell utasítani. Erre utal a Vht. 12. $\S(2)$ bekezdése is. Abban az esetben, ha a Vht. 9. §-a alapján alkalmazandó Pp. 130. § (1) bekezdés i) vagy j) pontja alapján ${ }^{39}$ utasítja el a bíróság a bekapcsolódás iránti kérelmet, a Pp. 132. §-a értelmében a zálogjogosult azt az elutasító végzés jogerőre emelkedésétől számított 30 napon belül ismételten benyújthatja, és ha az szabályszerü, a korábban benyújtott kérelem jogi hatályai fennmaradnak. Ez azért is különösen lényeges, mert a bekapcsolódás iránti kérelem határidöhöz kötött. A Vht. ugyan e körben nem utal arra, hogy a bekapcsolódás iránti kérelemre a keresetlevél benyújtására és elutasítására vonatkozó rendelkezések lennének irányadók, de nem is zárja ki azt. Ebben az esetben az a jogi képviselő nélkül eljáró fél sem veszítené el a jogát arra, hogy igényét érvényesítse, aki a felhívás ellenére nem pótolta teljes körüen a hiányokat.

A bizonytalanságok elkerülése céljából indokolt lenne ebben a körben a Vht. pontosítása.

\subsection{Fellebbezés a bekapcsolódás iránti kérelmet elutasító végzéssel szemben}

A végzés ellen fellebbezésnek van helye. A végzést kézbesíteni kell a zálogjogosultnak, az adósnak, a végrehajtást kérőnek és a végrehajtónak, ${ }^{40}$ fellebbezési joga azonban csak a feleknek és a zálogjogosultnak van ${ }^{41} \mathrm{~A}$ fellebbezési jog korlátozott, ugyanis ha az adós vagy a végrehajtást kérő a jogalapot vagy az összegszerüséget nem vitatta, vagy az összegszerüséget a zálogjogosult kérelmében foglalttól eltérő összegben nem ismerte el, továbbá ha nyilatkozatában a követelés fennállását vagy összegszerüségét elismerte, ezzel ellentétes álláspontját fellebbezéssel sem érvényesítheti. ${ }^{42} \mathrm{~A}$ szabály célja, hogy a végrehajtási eljárás elhúzódását, illetve a zálogjogosult érdekeinek csorbítására tett kísérletet megakadályozza. ${ }^{43}$

\footnotetext{
${ }^{39}$ A Pp. 130. § i) pontja szerint a bíróság a keresetlevelet idézés kibocsátása nélkül elutasítja, ha a 124 . § (2) bekezdésében foglalt ok áll fenn. Utóbbi szerint a bíróság a keresetlevelet - hiánypótlási felhívás kiadását mellözve - idézés kibocsátása nélkül elutasítja, ha a) a jogi képviselővel eljáró fél keresetlevele nem tartalmazza a 121. $\S(1)$ bekezdésében és a 121/A. $\S(2)$ bekezdésének a) vagy b) pontjában foglaltakat vagy b) a jogi képviselő nem csatolta a meghatalmazását vagy c) a jogi képviselővel eljáró fél elmulasztotta az eljárási illeték megfizetésére vonatkozó kötelezettség teljesítését. A Pp. 130. §j) pontja szerint a bíróság a keresetlevelet idézés kibocsátása nélkül elutasítja, a felperes a hiánypótlás végett (95. §) neki visszaadott keresetlevelet a kitűzött határidő alatt nem adta be, vagy újból hiányosan adta be, és emiatt a keresetlevél nem bírálható el.

40 Vht. 114/A. § (8) bekezdés.

41 Vht. 114/A. $§(9)$ bekezdés.

42 Vht. 114/A. § (9) bekezdés.

${ }^{43}$ CompLex Jogtár, Nagykommentár, Vht. 114/A. § (9) bekezdéséhez füzött magyarázat.
} 


\section{A felfüggesztés megszüntetése}

A felfüggesztés végső határidejét nem lehet elöre bizonyossággal meghatározni. A bíróság intézkedik a végrehajtás felfüggesztésének megszüntetéséröl, amennyiben a bekapcsolódást engedélyező végzés jogeröre emelkedik, és erről a végrehajtót értesíti.

Amennyiben a bíróság a bekapcsolódás iránti kérelmet az adós vagy a végrehajtást kérő vitatása miatt elutasította, a bíróság akkor szüntetheti meg a végrehajtás felfüggesztését, ha a jogosult nem igazolta, hogy a végzés kézhezvételétöl számított 8 munkanapon belül zálogjogból fakadó igénye érvényesítésére a pert megindította. ${ }^{44}$ Elképzelhető, hogy a végrehajtás felfüggesztését követően kerül sor a bekapcsolódás iránti kérelem érdemi vizsgálat nélkül történő elutasítására. A Vht. kifejezetten nem nevesíti, de az 51. § értelmében ebben az esetben az elutasító végzés jogeröre emelkedését követően szintén rendelkezni kell a felfüggesztés megszüntetéséröl és a végrehajtási eljárás folytatásáról.

A bírói gyakorlat nem egyöntetü annak a kérdésnek a megítélésében, hogy a felfüggesztést megszüntető végzés ellen van-e helye fellebbezésnek. Egyesek úgy vélekednek, hogy olyan súlyú döntésröl van szó, amely indokolja a jogorvoslati lehetőség biztosítását, mások amellett érvelnek, és magam is azzal az állásponttal értek egyet, hogy nincs helye fellebbezésnek, mert a felfüggesztés megszünése valójában a törvényen alapul, jogerős döntéshez kapcsolódó járulékos jellegü intézkedés, nem mérlegelést igénylő döntés eredménye.

\section{9. Összegzés}

A zálogjogosulti bekapcsolódásra vonatkozó szerteágazó joggyakorlat tükrözi, hogy e körben a Vht. rendelkezései hiányosak, illetve pontositásra szorulnak. A következő kérdésekkel, illetve problémákkal a jogalkotás szintjén kellene foglalkozni: a) A végrehajtást kérő is bekapcsolódhat a saját maga által indított végrehajtásba, ha a zálogjoga nem a végrehajtható okiratban foglalt követelés biztosítására áll fenn. b) Több végrehajtást kérő által ugyanazon adós ellen indított, egymáshoz csatolt ügyekben milyen módon kerülhet sor a bekapcsolódásra. c) Szünetelö végrehajtás esetén mi a követendő eljárás. d) A jogon és követelésen fennálló zálogjog jogosultjának helyzete szintén rendezendő.

A jogszabályi hiányosságokon kívül a bizonytalanságok oka továbbá az is, hogy a Vht. csupán szük körben engedi meg a felülvizsgálatot, így nincsenek irányadó kúriai határozatok. A joggyakorlatot nagyban könnyítené egy részletes kommentár, illetve a témát feldolgozó tanulmányok megjelenése is.

44 Vht. 114/A. § (7) bekezdés. 


\begin{abstract}
Lien is substantially characterized by priority in satisfaction, which is in the spotlight of the execution of the lien. The lien's function and force as a security interest is determined by the rules of execution. Under Act V of 2013 on the Civil Code, out-of-court execution has become the main rule, however, judicial execution and liquidation proceedings remained available to enforce the lien. Furthermore, in order to protect the purpose of the pledge to serve as a collateral and to provide priority in satisfaction, the lien may also be enforced where the pledge has been seized and offered for sale in the execution proceedings initiated by a person other than the lien holder. In this case, the lien holder may join in the execution proceedings even if his/ her claim against the lienee as debtor is not yet due. Otherwise, upon auctioning the pledge, the lien holder's lien would terminate. The purpose of this study is to identify and address the issues of this specific type of execution that arise during implementation as well as the incompleteness of the applicable laws and regulations.
\end{abstract}

